\title{
PARAMETRIKUS MODELLBIZONYTALANSÁG EGY ANYAGVIZSGÁLATI PÉLDA
}

\section{PARAMETRICAL MODEL UNCERTAINTY A MATERIALS TESTING EXAMPLE}

\author{
Nagyné Halász Erzsébet ${ }^{1}$, Pokorádi László ${ }^{2}$ \\ ${ }^{I}$ Óbudai Egyetem, Bánki Kar, Anyagtudományi és Gyártástechnológiai Intézet, \\ H-1081, Magyarország, Budapest, Népszinház utca, 8. Tel. +36 16665315 , \\ nagynei.halasz@bgk.uni-obuda.hu \\ 2 Óbudai Egyetem, Bánki Kar, Biztonságtechnikai Intézeti Tanszék, \\ H-1081, Magyarország, Budapest, Népszínház utca, 8. Tel. +36 30 9194929, \\ pokoradi.laszlo@bgk.uni-obuda.hu
}

\begin{abstract}
During engineering calculations parametric uncertainty can be seen that can be modeled and is described by appropriate methods. One of the aims of material testing is the surface hardness determination. Tis study describes the main methods for describing the parametric uncertainties and they are illustrated through an example of material testing.
\end{abstract}

Keywords: modeling, uncertainty, materials testing.

\section{Összefoglalás}

A mérnöki, műszaki számítások során parametrikus bizonytalanság tapasztalható, mely megfelelő módszerekkel modellezhető és leírható. Az anyagvizsgálati eljárások egyik célja lehet a fémek, fémfelületek keménység meghatározása. A tanulmány bemutatja a parametrikus bizonytalanságot leíró főbb módszereket és azokat egy anyagvizsgálati példán keresztül szemlélteti.

Kulcsszavak: modellezés, bizonytalanság, anyagvizsgálat.

\section{Bevezetés}

A müszaki tudományok egyik fő feladata valós fizikai jelenségek folyamatok vagy rendszerek modelljeinek felállítása és vizsgálata. A matematikai modelleket és paramétereket a modellezett rendszer természete és a megkívánt pontosságú eredmény függvényében kell kiválasztanunk. A gerjesztések, valamint a belső jellemzők helyes feldolgozása biztosítja, hogy a rendszer valós tulajdonságai tükröződnek az eredményekben. Ezért kritikus kérdés a megfelelő modell és a rendelkezésre álló adatok helyes feldolgozása.
Az alkatrészek szilárdságtani vizsgálatának egyik módszere a keménységmérés. A szúró keménységmérések közé tartozik a Vickers módszer mikro és nano keménységmérése. A nano keménységmérés a bevonatok keménységének meghatározására alkalmas.

A mérnöki gyakorlatban alkalmazott modelleket írja le M. Csizmadia és Nándori [3]. A modellbizonytalanságokkal Pokorádi foglalkozik [4] könyvében. Kovács-Coskun és Bitay dolgozatának célja a felületi megmunkált, alakított réteg elemzése volt [1]. Kovács-Coskun és Pinke a CSM MHT keménységmérö alkalmazását mutatta be vé- 
kony felületi rétegek vizsgálatánál [2]. A metallográfiai és anyagvizsgálati alapokat Zorkóczy foglalta össze [5].

A tanulmány során a Szerzők - a fenti irodalmakra támaszkodva - mutatják be a parametrikus bizonytalanságot és azt egy anyagvizsgálati példán keresztül szemléltetik.

A tanulmány az alábbi részekből áll: A 2. fejezet a Vickers-keménység mérést írja le. A 3. fejezet a modellbizonytalanság kérdéseit elemzi. A 4. fejezet egy mikro keménységmérési példán szemlélteti a parametrikus bizonytalanságot. Az 5. fejezet összegzi a tanulmány elkészítésekor szerzett tapasztalatokat.

\section{A Vickers-keménység mérés le- írása}

Vickers-keménység (HV) keménységmérést $136^{\circ}$-os csúcsszögü négyzet alapú gyémántgúlának $F$ terheléssel a tárgy felületébe való benyomása útján végzik úgy, hogy a közel négyzetes lenyomat két átlóját mérik és azok közepertekebő1 (d) számítják a lenyomat felületet (1. ábra).

$$
H V=\frac{F}{A}
$$

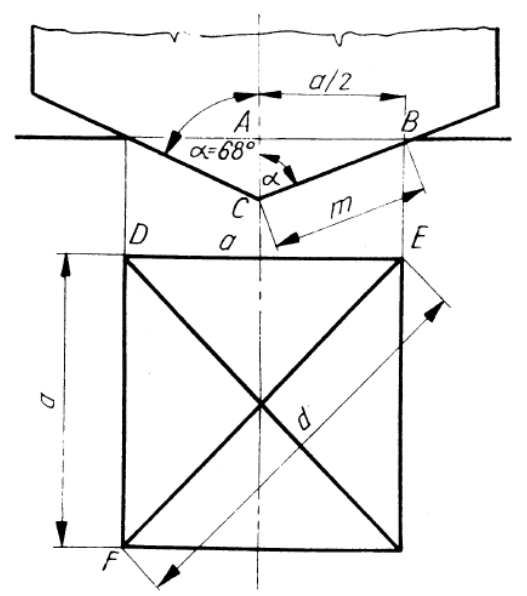

1. ábra. A Vickers-keménység mérés lenyomatának geometriai alakja
Az 1. ábra jelölései alapján:

$$
A=4 \frac{a m}{2},
$$

illetve, az 1. ábra $\mathrm{ABC}$ háromszögének szögeiböl következik, hogy

$$
\begin{aligned}
& \frac{a}{2 m}=\sin \alpha, \\
& A=\frac{d^{2}}{2 \sin \alpha} .
\end{aligned}
$$

Mivel a gyémánt gúla csúcs szöge (névlegesen) $136^{\circ}$, az $\alpha=68^{\circ}$, azaz $\sin \alpha=$ 0,9272 , ekkor a

$$
\begin{aligned}
& A=\frac{d^{2}}{1,854} \\
& H V=\frac{1,854 F}{d^{2}}
\end{aligned}
$$

egyszerüsített egyenleteket tudjuk alkalmazni. A gyakorlatban azonban nem a fenti számítást alkalmazzák, hanem táblázat alapján határozzák meg a HV értéket [3].

\section{A modellbizonytalanság}

A mérnöki gyakorlatban a rendelkezésünkre álló információk gyakran nem kellöen pontosak - inkább pontatlan, diffúz, fluktuáló, nem teljes, töredékes. Ezeket az információkat föleg tervek, tervrajzok, mérések, megfigyelések, tapasztalatok, szakértői ismeretek, és elöírások alapján nyerhetjük. Ráadásul, ezeket az adatokat a gyártás, üzemeltetés során bekövetkező emberi tévedések, hibák, illetve a környezet paramétereinek sztochasztikus változásai is befolyásolják. A fenti jelenségeket egy általános kifejezéssel tudjuk összegezni, ez a bizonytalanság [4]. A bizonytalanság elválaszthatatlan a mérnöki számításoktól. A bizonytalanságelemzés információt ad a számítások hibahatárairól, és így eredményeinek elfogadási szintjéről. 
A rendelkezésre álló információk bizonytalansága megakadályozhatja a helyes számítási eredmények meghatározását. Itt fontos felidézni M. Csizmadia és Nándori szerzőpáros az [3] irodalomban leírt gondolatát: „Az a jó modell, amely a lehetö legegyszerübb, de a célnak megfelelö pontossággal közelíti a valóságot." Másképpen megfogalmazva: Az, és csak az a modell tekinthető jónak, amely a vizsgálat szempontjából fontos paramétereket, összefüggéseket és a peremfeltételeket megfelelő pontossággal figyelembe veszi, egyben mindazon másodlagos jellemzőket elhanyagolja, amelyeket a kitüzött vizsgálat szempontjából nem tekintünk meghatározónak.

A bizonytalanság forrása alapján megkülönböztetünk parametrikus és ismereti bizonytalanságot.

$\mathrm{Az}$ ismereti bizonytalanság szubjektív bizonytalanságként szemlélhető, fö oka a nem megfelelő szakmai ismeret. A dolgozatunkban bemutatott vizsgálat során például ismereti bizonytalanság lehet, ha rossz keménység meghatározási modellt (például a Brinell módszert) alkalmazunk.

A parametrikus bizonytalanság elsődlegesen az objektivitáshoz kapcsolható. Következésképpen, a parametrikus bizonytalanság megfelelő módszerekkel modellezhető és dolgozható fel.

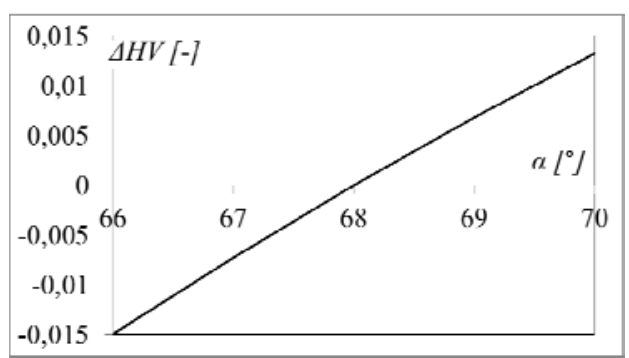

2. ábra. A gúla fél-csúcsszög eltérésének relativ hatása a számitási eredményre

Például, a Vickers-keménység mérése esetén az egyik bizonytalansági forrás lehet a gyémánt gúla csúcsszöge, annak pontat- lansága. A 2. ábra a mérési gúla félcsúcsszög eltérésének mérési eredményre gyakorolt relatív hatását szemlélteti.

A másik - inkább a mérést végző személytől, annak tapasztalatától függő - bizonytalanság forrás a közel négyzetes lenyomat két átlója hosszának meghatározása, lemérése. Az általunk használt mérőberendezéssel $1 \mu \mathrm{m}$ pontosan tudjuk meghatározni a lenyomat méreteit. A 3. ábra szemlélteti a mérési pontatlanságból (bizonytalanságból) származó relatív eltéréseket. A szemléltetéshez alkalmazott példa névleges terhelése $0,2 \mathrm{~kg}$, illetve a lenyomat átlóinak átlaga $150 \mu \mathrm{m}$.

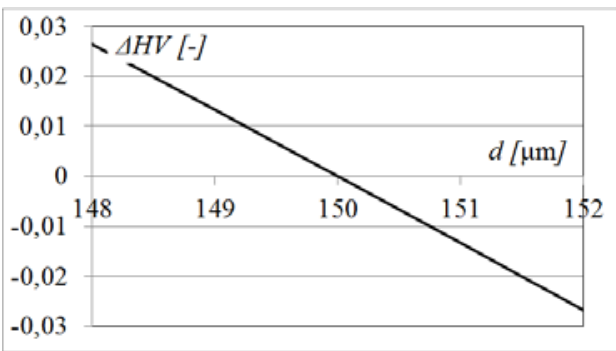

3. ábra. A mérési pontatlanság relatív hatása a számítási eredményre

Természetesen, más - például a mért anyag inhomogenitásából származó - bizonytalansági források is léteznek, melyek leírásától, terjedelmi okok miatt eltekintünk.

A két bemutatott példából látható, hogy nagyságrendileg maximum $3 \%$-os számítási bizonytalanság tapasztalható. Ez más mérnöki területen ez jelentős probléma lehet. A méréseket végző szakemberek véleménye szerint az ekkora mérvủ eltérések nem szignifikánsak. Ez viszont rámutat arra, hogy a parametrikus bizonytalanság mértéke szakma-specifikus módon kell értelmezni.

\section{Esettanulmány}

Egy tudományos kutatómunka keretében hegesztett szerkezet varrat és hőhatás 
övezet mikro-keménységmérését végeztük el. Az elemzés során két összehegesztett S355 jelü, $40 \mathrm{~mm}$ vastag acéllemezt vizsgáltunk, több mintadarab esetén.

A mikro-keménységméréshez ZWICK 3212 típusú mérőberendezést alkalmaztunk, $0,2 \mathrm{~kg}$ terheléssel. A 4. ábrán az egyik mért varrat és hőhatás övezet látható a mérési pontokkal. A mérési eredményeket az 1. táblázat tartalmazza.

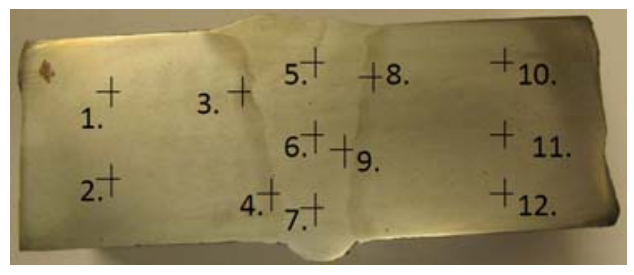

4. ábra Keménységmérési pontok

1. táblázat. keménységmérési eredmények

\begin{tabular}{|c|c|c|r|}
\hline$i$ & $\begin{array}{c}d i \\
{[\mu m]}\end{array}$ & $\begin{array}{c}H V_{0,2 i} \\
{[-]}\end{array}$ & $\begin{array}{c}\Delta H V_{0,2 i} \\
{[-]}\end{array}$ \\
\hline 1 & 43 & 198 & $-0,026$ \\
\hline 2 & 43 & 198 & $-0,026$ \\
\hline 3 & 41 & 221 & 0,087 \\
\hline 4 & 42 & 214 & 0,052 \\
\hline 5 & 41 & 221 & 0,087 \\
\hline 6 & 41 & 221 & 0,087 \\
\hline 7 & 43 & 198 & $-0,026$ \\
\hline 8 & 42 & 207 & 0,018 \\
\hline 9 & 43 & 198 & $-0,026$ \\
\hline 10 & 43 & 198 & $-0,026$ \\
\hline 11 & 45 & 183 & $-0,100$ \\
\hline 12 & 45 & 183 & $-0,100$ \\
\hline
\end{tabular}

Az 1. táblázat $\Delta H V_{0,2 i}$ oszlopa a meghatározott keménységi értékek relatív eltérését mutatja az átlagos keménység értéktől. Látható, hogy a maximális relatív differencia 0,1-es (más szóval 10\%-os). Ez az eltérés ezen müszaki tudományterületen nem számít szignifikánsnak. Kijelenthető, hogy az elvégzett hegesztés megfelelő.

\section{Következtetések}

Dolgozatunk röviden bemutatta és egy anyagvizsgálati (mikro-keménységmérési) példán keresztül szemléltette a parametrikus modell bizonytalanságot. Célunk a néha csak elméleti fejtegetésnek tünő kérdéskör gyakorlati mérnöki példával való bemutatása, értelmezése.

\section{Szakirodalmi hivatkozások}

[1] Kovács-Coskun, Tünde; Bitay, Enikő: $A$ felület vizsgálata mikrokeménységméréssel, Óbuda University e-Bulletin Vol. 2, No. 1, 2011. pp. 365-370.

[2] Kovács-Coskun, Tünde., Pinke, Péter: CSM MHT keménységmérö alkalmazása vékony felületi rétegek vizsgálatánál, Nemzetközi Gépész, Mechatronikai és Biztonságtechnikai Szimpózium, 2010. november 10-11, Óbudai Egyetem, Budapest

[3] M. Csizmadia, Béla; Nándori, Ernő: Modellalkotás, Nemzeti Tankönyvkiadó, Budapest, 2003.

[4] Pokorádi, László: Rendszerek és folyamatok modellezése, Campus Kiadó, Debrecen, 2008.

[5] Zorkóczy, Béla: Metallográfia és anyagvizsgálat, Nemzeti Tankönyvkiadó, Budapest, 1968. p. 476. 